\title{
The Atomic-Level Structure of Cementitious Calcium Aluminate Silicate Hydrate Determined by NMR
}

\author{
Pinelopi Moutzouri§ and Lyndon Emsley* \\ §SCS-Metrohm award for best oral presentation in Inorganic \& Coordination Chemistry
}

\begin{abstract}
We review our recent paper which resolves the long-standing dilemma of the location and nature of the six-fold coordinated aluminum in calcium aluminate silicate hydrate (C-A-S-H) samples. First principles calculations predict that at high $\mathrm{Ca}: \mathrm{Si}$ and $\mathrm{H}_{2} \mathrm{O}$ ratios, aluminum is incorporated into the bridging sites of the linear silicate chains and that the stable coordination number is six. We confirm this hypothesis experimentally by one- and two-dimensional dynamic nuclear polarization enhanced ${ }^{27} \mathrm{Al}$ and ${ }^{29} \mathrm{Si}$ solid-state NMR experiments in which we correlate the distinctive six-fold coordinated aluminum NMR signal at $5 \mathrm{ppm}$ to ${ }^{29} \mathrm{Si}$ NMR signals from silicates in C-A-S-H.
\end{abstract}

Keywords: C-A-S-H · DNP · MAS · Six-fold coordinated aluminum · Solid-State NMR

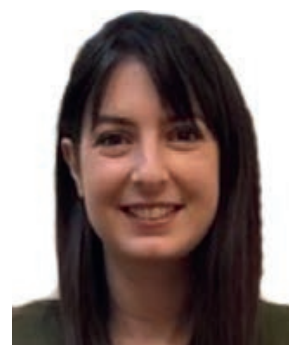

Pinelopi Moutzouri obtained her Bachelor's degree in Pharmacy with honours at the University of Patras in 2015. She then moved to Manchester to carry out her $\mathrm{PhD}$ studies in liquid state NMR spectroscopy under the supervision of Prof. Gareth Morris and Prof. Mathias Nilsson and with industrial funding from AstraZeneca. In 2018, she moved to Lausanne and EPFL where she is currently carrying out her postdoctoral research in the group of Prof. Lyndon Emsley working on the application and the development of new methods for Ultra-fast MAS Solid State NMR and Dynamic Nuclear Polarization.

\section{Introduction}

Concrete is the most abundant manmade material. As calculated for the 2018 cement production, ${ }^{[1]}$ around 2 gigatons are produced annually. However, concrete is also responsible for a large carbon footprint and the most promising route towards a more eco-friendly material is by the partial substitution of Portland cement with supplementary cementitious materials (SCMs), such as fly ash, limestone, blast furnace slag, and calcined clays. ${ }^{[2-6]}$ Many of these SCMs contain aluminum and have calcium aluminate silicate hydrate $(\mathrm{C}-\mathrm{A}-\mathrm{S}-\mathrm{H})$ as their main hydration product. $\mathrm{C}-\mathrm{A}-\mathrm{S}-\mathrm{H}$ is a calcium silicate hydrate $(\mathrm{C}-\mathrm{S}-\mathrm{H})^{[7,8]}$ which incorporates aluminum into its structure. However, the addition of SCMs has an impact on the reactivity of the material, increasing its setting time and consequently leading to loss of workability. As a result, the effects of SCMs on cement hydration have been extensively studied. ${ }^{[9-12]}$ One remaining key question involves the atomic level structure of the main phase that is produced during blended cement hydration.
The hydration of ordinary Portland cement produces C-S-H with a variable $\mathrm{Ca}: \mathrm{Si}$ and $\mathrm{H}_{2} \mathrm{O}: \mathrm{Si}$ stoichiometry. ${ }^{[13,14]} \mathrm{C}-\mathrm{S}-\mathrm{H}$ has a structure similar to the mineral tobermorite, with a $\mathrm{Ca}-\mathrm{O}$ main layer, linear silicate chains, and a disordered interlayer space containing water molecules, calcium ions and hydroxyl groups. ${ }^{[8,15-17]}$ There are three types of silicate species in C-S-H: chain-terminating tetrahedra, pairing tetrahedra, and interlayer-protruding bridging tetrahedra.

In C-A-S-H, solid-state ${ }^{27} \mathrm{Al}$ NMR shows three different types of aluminates: four-coordinate ${ }^{[4]} \mathrm{Al}$, five-coordinate ${ }^{[5]} \mathrm{Al}$, and sixcoordinate ${ }^{[6]} \mathrm{Al}$ species. ${ }^{[18-20]}{ }^{[4]} \mathrm{Al}$ species are known to substitute bridging-type silicate species, ${ }^{[19-24]}{ }^{[5]} \mathrm{Al}$ is believed to charge compensate the incorporation of ${ }^{[4]} \mathrm{Al}$ in the silicate chain by being present in the interlayer, ${ }^{[18-20,25,26]}$ or associates with the C-A-S-H surface. ${ }^{[27]}$ Lastly, ${ }^{[6]} \mathrm{Al}$ possesses octahedral geometry and in the work by Faucon et al. ${ }^{[20]}$ where it was associated with an NMR signal at $5 \mathrm{ppm}$, it was proposed to substitute for $\mathrm{Ca}^{2+}$ into the main $\mathrm{CaO}$ layer of $\mathrm{C}-\mathrm{S}-\mathrm{H}$. This assignment, however, was challenged by Andersen and coworkers whose experiments suggested that ${ }^{[6]} \mathrm{Al}$ occurs as an $\mathrm{AlO}_{\mathrm{x}}(\mathrm{OH})_{6-\mathrm{x}}{ }^{(3+\mathrm{x})-}$ species which does not correspond to an ${ }^{[6]} \mathrm{Al}$ species within the $\mathrm{C}-\mathrm{S}-\mathrm{H}$ but can be assigned to a different phase, the so-called 'third aluminate hydrate' (TAH). Their hypothesis was based on the observation that the ${ }^{[6]} \mathrm{Al}$ NMR signal is lost at elevated temperatures $\left(>70{ }^{\circ} \mathrm{C}\right)$ while the silicate framework structure is unperturbed. ${ }^{[18]}$ Nevertheless, TAH was never characterized or identified by any other method aside from solid-state ${ }^{27} \mathrm{Al}$ NMR.

In our recent work, ${ }^{[28]}$ we re-examined the nature of ${ }^{[6]} \mathrm{Al}$ incorporation into $\mathrm{C}-\mathrm{S}-\mathrm{H}$ and determined the atomic-level structure of C-A-S-H by a combination of computational predictions and experimental NMR. We extended the recently developed atomic level brick model of C-S-H, to build atomic-level C-A-S-H structural units, ${ }^{[29]}$ whereas experimental evidence was obtained with dynamic nuclear polarization (DNP) enhanced solid-state magicangle-spinning (MAS) NMR spectroscopy. DNP is a hyperpolarization technique that significantly enhances the solid-state NMR signal intensity by transferring high electron spin polarization from unpaired electrons to nuclei upon microwave irradia- 
tion $^{[30-33]}$ and yields the sensitivity to perform highly demanding one- and two-dimensional $\left\{{ }^{29} \mathrm{Si}\right\}{ }^{27} \mathrm{Al}$ correlation NMR experiments that give valuable structural information. Our findings were inconsistent with the TAH hypothesis, and we determined that ${ }^{[6]} \mathrm{Al}$ is incorporated into bridging sites within the silicate chain framework of C-A-S-H at high $\mathrm{Ca}: \mathrm{Si}$, high $\mathrm{H}_{2} \mathrm{O}: \mathrm{Si}$, and low $\mathrm{Al}: \mathrm{Si}$ ratios. ${ }^{[28]}$

\section{Results and Discussion}

\subsection{Stability of Aluminate Species in $\mathbf{C}-\mathbf{A}-\mathbf{S}-\boldsymbol{H}$}

Fig. 1 illustrates a C-A-S-H structure constructed using the brick model. Similarly to C-S-H, linear silicate chains are flanking a $\mathrm{CaO}$ main layer, $\mathrm{Ca}_{\mathrm{ML}}$ whereas 'pairing' silicates, $\mathrm{Q}^{(2 \mathrm{p})}$, interlayer-protruding 'bridging' silicate species, $\mathrm{Q}^{(2 \mathrm{~b})}$, and defects where $\mathrm{Q}^{(1)}$ silicate species terminate the chains are observed.[16] The interlayer contains water and calcium as $\mathrm{Ca}^{2+}, \mathrm{CaOH}^{+}$ions or $\mathrm{Ca}(\mathrm{OH})_{2}$ units, ${ }^{[8,29]}$ depicted as $\mathrm{Ca}_{\mathrm{IL}}$ species. The structure includes also four-, five-, and six-fold coordinate aluminate species into the silicate chains or in the interlayer and an additional classification of $\mathrm{Q}^{(\mathrm{n})}$ species according to the number and type of aluminate species to which they are bonded.

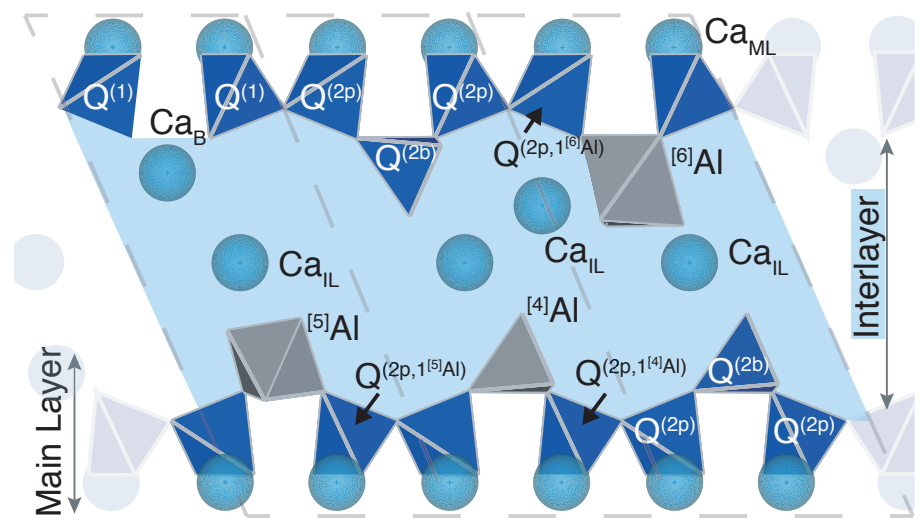

Fig. 1. Schematic showing three C-A-S-H structural units representing the layered bulk structure of C-A-S-H. The calcium atoms, $\mathrm{Ca}_{\| L}$, are depicted as turquoise spheres. The interlayer is shown in light blue color omitting for clarity water and hydroxyl ions. The dark blue silicate species are labelled based on their connectivity and position. The polyhedral shapes of aluminum are shown in grey. Reproduced from ref. [28] with permission.

The analysis of the energetics of aluminate species within structural units with different $\mathrm{Ca}$ :Si ratios was done using density functional theory (DFT) calculations and in Fig. 2 the relative energies due to the different coordination geometries of aluminum at a fixed stoichiometry are compared. At the low $\mathrm{Ca}$ :Si ratios of about 1.0 encountered in industry, ${ }^{[3]}$ the calculations agreed with existing structural models of $\mathrm{Al}$ in $\mathrm{C}-\mathrm{A}-\mathrm{S}-\mathrm{H} \cdot{ }^{[34,35]}{ }^{[4]} \mathrm{Al}$ is relatively stable in contrast to ${ }^{[6]} \mathrm{Al}$ which is not expected to be a stable aluminate species at these low $\mathrm{Ca}: \mathrm{Si}$ ratios. As the $\mathrm{Ca}: \mathrm{Si}$ ratio increases, bridging ${ }^{[5]} \mathrm{Al}$ and ${ }^{[6]} \mathrm{Al}$ species may be more stable than ${ }^{[4]} \mathrm{Al}$ species, and at the highest $\mathrm{Ca}$ :Si ratio $(1.75),{ }^{[6]} \mathrm{Al}$ is about 0.3 $\mathrm{eV}$ more stable than the corresponding ${ }^{[4]} \mathrm{Al}$. The stabilization of ${ }^{[5]} \mathrm{Al}$ is intermediate, being at low $\mathrm{Ca}: \mathrm{Si}$ ratios less unstable than ${ }^{[6]} \mathrm{Al}$ but at higher $\mathrm{Ca}: \mathrm{Si}$ ratios less stable than ${ }^{[6]} \mathrm{Al}$. Therefore, we would not exclude the presence of bridging ${ }^{[5]} \mathrm{Al}$ in $\mathrm{C}-\mathrm{A}-\mathrm{S}-\mathrm{H}$ at any given $\mathrm{Ca}: \mathrm{Si}$ ratio. Lastly, we found that aluminates in the interlayer, regardless of initial coordination geometry, relax into a fivefold coordination geometry and thus infer that isolated interlayer aluminates in $\mathrm{C}-\mathrm{A}-\mathrm{S}-\mathrm{H}$ are less stable than bridging aluminates.

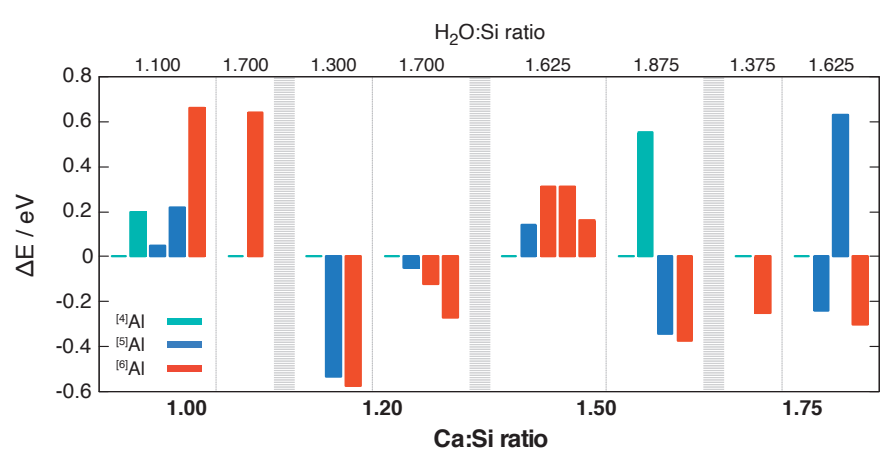

Fig. 2. Relative energies of bridging aluminates according to coordination $(\Delta E)$ from $\mathrm{C}-\mathrm{A}-\mathrm{S}-\mathrm{H}$ structural units of different $\mathrm{Ca}$ :Si and $\mathrm{H}_{2} \mathrm{O}$ :Si ratios. Thick vertical dashed grey lines divide the results into four regions on the basis of $\mathrm{Ca}$ :Si ratio, whereas thin vertical dashed grey lines subdivide each region of fixed $\mathrm{Ca}$ :Si ratio into two regions of fixed $\mathrm{H}_{2} \mathrm{O}: \mathrm{Si}$ ratios, yielding eight panels of fixed composition. Within each panel, the most stable C-A-S-H unit with Al in tetrahedral coordination is taken as the reference with a relative energy of $\Delta E=0$. Adapted from ref. [28] with permission.

These trends may be explained by the presence of hydroxyl groups as $\mathrm{H}_{2} \mathrm{O}: \mathrm{Si}$ and $\mathrm{Ca}: \mathrm{Si}$ ratios increase and infer that hydroxyl ligands help with the stabilization of ${ }^{[6]} \mathrm{Al}$ units in the silicate chain. For water itself, the calculations indicated that the relative stability of ${ }^{[6]} \mathrm{Al}$ is mostly independent of local water structure.

Our theoretical calculations therefore suggested that at sufficiently high $\mathrm{Ca}: \mathrm{Si}$ ratios, stable ${ }^{[6]} \mathrm{Al}$ species can substitute for bridging $\mathrm{Q}^{(2 \mathrm{~b})}$ species in the silica chain framework and be incorporated into the silicate chains of $\mathrm{C}-\mathrm{A}-\mathrm{S}-\mathrm{H}$. To support this, we turned to state-of-the-art synthetic and solid-state NMR methods.

\subsection{DNP-enhanced NMR of C-A-S-H}

To reduce the ambiguity caused by the material complexity of hydrated cement, we took advantage of the recently introduced rapid precipitation method which produces essentially pure $\mathrm{C}-\mathrm{S}-\mathrm{H}$ with a controllable $\mathrm{Ca}$ :Si ratio, ${ }^{[16]}$ and extends it to synthesize C-A-S-H with controllable Al:Si ratio. However, even with these simpler samples the bottleneck of the low sensitivity of the NMR experiments remains. To overcome this we prepared C-A-S-H formulations that would yield enhancement of NMR signals by MAS DNP[16,32,33,36] by incorporating a small amount of the organic biradical AMUPol to the sample. ${ }^{[37]}$ AMUPol at 100 $\mathrm{K}$ and with MAS can provide efficient transfer of large electron polarization to protons in the sample. Hyperpolarized ${ }^{1} \mathrm{H}$ magnetization can then be transferred to ${ }^{29} \mathrm{Si}$ or ${ }^{27} \mathrm{Al}$ nuclei by CP. ${ }^{[38]} \mathrm{DNP}$ enhancements of around 40 at $9.40 \mathrm{~T}$ and around 3 at $21.14 \mathrm{~T}$ were typical for both nuclei. The addition of a basic environment was necessary sometimes to improve DNP enhancements.

Fig. 3 shows a DNP-enhanced 1D ${ }^{27} \mathrm{Al}$ CP MAS NMR experiment for a C-A-S-H sample with a $\mathrm{Ca}: \mathrm{Si}$ ratio of 2.0 and an $\mathrm{Al}: \mathrm{Si}$ ratio of 0.04 at $21.14 \mathrm{~T}$. The conventional $\mathrm{CP}$ spectrum contains three signal regions around $75 \mathrm{ppm}, 40 \mathrm{ppm}$, and $5 \mathrm{ppm}$, corresponding to the well-known shifts of ${ }^{[4]} \mathrm{Al},{ }^{[5]} \mathrm{Al}$, and ${ }^{[6]} \mathrm{Al}$ aluminates, respectively. The ${ }^{[4]} \mathrm{Al}$ and ${ }^{[5]} \mathrm{Al}$ signals are broader, consistent with expected quadrupolar coupling constants $(|C|)$ of $3 \mathrm{MHz}$, whereas the ${ }^{[6]} \mathrm{Al}$ signals with the much lower $\left|C_{q}\right|$ near $1 \mathrm{MHz}^{[19]}$ show narrower peaks. At the region between 5 and $10 \mathrm{ppm}$, two distinct ${ }^{\left[{ }^{6]} \mathrm{Al}\right.}$ signals with respective maxima at $5.0 \mathrm{ppm}$, associated with the presence of C-A-S-H, and at $10.1 \mathrm{ppm}$, associated with ettringite, AFm phases, and siliceous hydrogarnet, ${ }^{[18,39]}$ are resolved.

In the same figure, ${ }^{29} \mathrm{Si}$ filtered ${ }^{27} \mathrm{Al} \mathrm{DNP} N \mathrm{NR}$ experiment is also shown. In this experiment, ${ }^{1} \mathrm{H}$ polarization enhanced by DNP is initially transferred to ${ }^{29} \mathrm{Si}$ nuclei by $\mathrm{CP}$, and then to ${ }^{27} \mathrm{Al}$ for detection through a refocused dipolar INEPT sequence. ${ }^{[40]}$ In this 


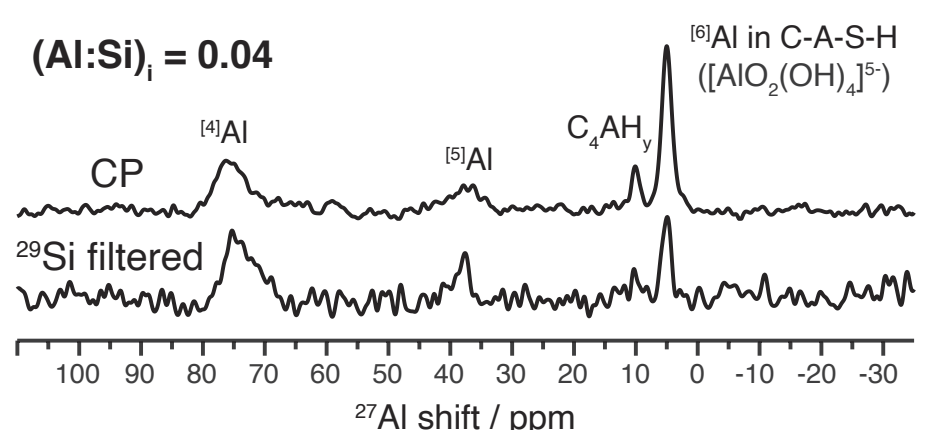

Fig. 3. DNP enhanced ${ }^{27} \mathrm{Al}$ CP MAS spectrum at $21.14 \mathrm{~T}, 100 \mathrm{~K}$, and $12.5 \mathrm{kHz}$ MAS for a synthetic C-A-S-H sample having Ca:Si ratio of 2.0 and initial $\mathrm{Al}$ :Si ratio of 0.04 with and without the application of a ${ }^{29} \mathrm{Si}$ filter. The CP selects for nuclei in proton-containing phases. Additionally, the ${ }^{29} \mathrm{Si}$ filter selects NMR signal from those ${ }^{27} \mathrm{Al}$ nuclei in proximity to ${ }^{29} \mathrm{Si}$ nuclei. $\mathrm{C}_{4} \mathrm{AH}_{\mathrm{y}}$ is shorthand for hydroxylated $\mathrm{AFm}$ phases. Adapted from ref. [28] with permission.

sequence the transfer is mediated by the through-space dipolar coupling between ${ }^{29} \mathrm{Si}$ and ${ }^{27} \mathrm{Al}$ nuclei which scales with the distance between the two nuclei. Thus, this experiment allows only those ${ }^{27} \mathrm{Al}$ close enough to ${ }^{29} \mathrm{Si}$ nuclei to be detected. In this case, short recoupling intervals were used, probing distances up to 2.46 $\AA$, which implies that the detected ${ }^{27} \mathrm{Al}$ species are directly bonded to silicates. Crucially, the ${ }^{[6]} \mathrm{Al}$ signal at $5.0 \mathrm{ppm}$ survived the ${ }^{29} \mathrm{Si}$ filtering confirming its presence within a silicate containing phase - C-A-S-H. In contrast the signal at $10.1 \mathrm{ppm}$, believed to belong to a hydroxylated AFm signal, was not detected in the ${ }^{29} \mathrm{Si}$ filtered spectrum which is consistent with the lack of $\mathrm{Si}$ in this phase.

\subsection{Assignment of the $5 \mathrm{ppm}{ }^{27} \mathrm{Al}$ NMR Signal}

To localize ${ }^{[6]} \mathrm{Al}$ more precisely within $\mathrm{C}-\mathrm{A}-\mathrm{S}-\mathrm{H}$, and correlate ${ }^{27} \mathrm{Al}$ and ${ }^{29} \mathrm{Si}$ frequencies, we performed a two-dimensional version of the ${ }^{29} \mathrm{Si}$ filtered experiment. Due to even more demanding sensitivity issues, the experiment was performed with a C-A-S-H sample of a $0.07 \mathrm{Al}$ :Si ratio and at a lower magnetic field of $9.40 \mathrm{~T}$, where DNP is known to perform better ${ }^{[31,32]}$ and which led to better enhancements. A longer recoupling time was also used, probing distances up to $4.33 \AA$, to increase even more the sensitivity.

In the 2D DNP enhanced $\left\{{ }^{29} \mathrm{Si}\right\}{ }^{27} \mathrm{Al}$ refocused dipolar INEPT correlation spectrum shown in Fig. 4a, two main correlation peaks can be observed. The most intense one, labelled as $\mathrm{Q}^{(2 \mathrm{p}, 1[4] \mathrm{Al})}$, corresponds to the well-known tetrahedral ${ }^{[4]} \mathrm{Al}-\mathrm{O}-\mathrm{Si}$ bonding motif in C-A-S-H ${ }^{[23,41]}$ and correlates ${ }^{[4]} \mathrm{Al}$ species with ${ }^{29} \mathrm{Si}$ chemical shifts peaking at $-81 \mathrm{ppm}$, placing ${ }^{[4]} \mathrm{Al}$ in a bridging site. The second, weaker correlation, correlates the C-A-S-H ${ }^{[6]} \mathrm{Al}$ of primary interest with silicates shifts peaking around $-77 \mathrm{ppm}$, lower than in the previous correlation. This silicate shift is associated with terminating $\mathrm{Q}^{(1)}$ silicate species and it could suggest that ${ }^{\left[{ }^{[6}\right.} \mathrm{Al}$ species exist in the interlayer. However, our DFT results strongly indicated that this scenario would lead to an unstable ${ }^{[6]} \mathrm{Al}$ species. Alternatively, this silicate shift may belong to silicates more deshielded than the silicates correlating with ${ }^{[4]} \mathrm{Al}$ species. ${ }^{[42]}$ This can be explained if we take into account the aluminate coordination. Al-O bond lengths are affected by electron density and as a result electrostatically these bond lengths should be greater in an $\mathrm{AlO}_{6}$ octahedron than in an $\mathrm{AlO}_{4}$ tetrahedron. Longer and therefore less covalent ${ }^{[6]} \mathrm{Al}-\mathrm{O}$ bonds lead to more covalent and shorter $\mathrm{Si}-\mathrm{O}$ bonds which as a result leads to an isotropic deshielding of the ${ }^{29} \mathrm{Si}$ nucleus. ${ }^{[43,44]}$ As can be seen in Table 1 this can also be explained by our DFT optimized structures.

In Fig. 4b, we calculated ${ }^{29} \mathrm{Si}$ chemical shifts of the $\mathrm{Q}^{(2 \mathrm{p}, 1 \mathrm{Al})}$ species in the DFT optimized structures which indeed showed and confirmed the existence of the proposed deshielding effect. The mean ${ }^{29} \mathrm{Si}$ chemical shift values we calculated for the $\mathrm{Q}^{(2 \mathrm{p}, 1[6] \mathrm{Al})}$
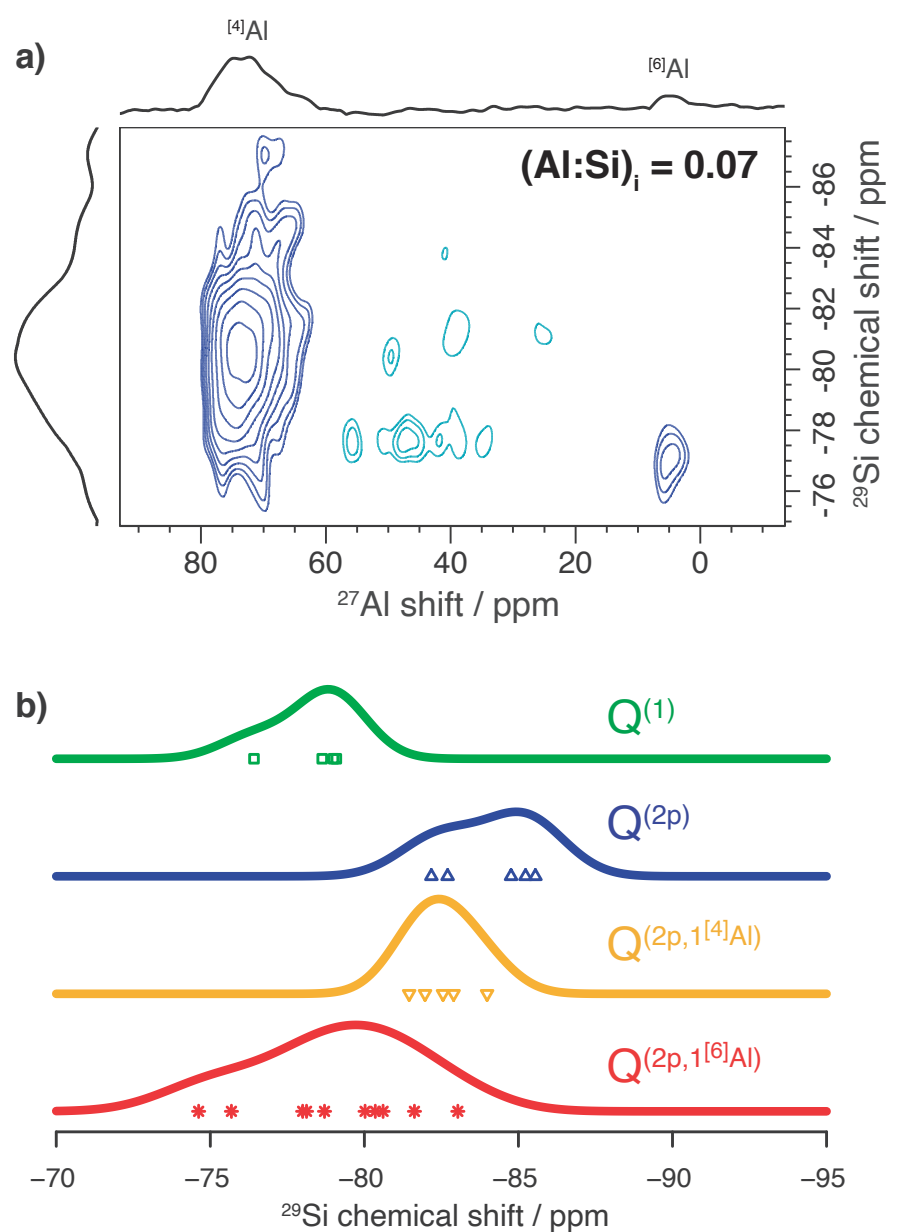

Fig. 4. a) A DNP enhanced two-dimensional $\left\{{ }^{29} \mathrm{Si}\right\}{ }^{27} \mathrm{Al}$ refocused dipolar INEPT MAS spectrum at $9.40 \mathrm{~T}, 100 \mathrm{~K}$, and $10 \mathrm{kHz}$ MAS for a synthetic C-A-S-H sample having $\mathrm{Ca}$ :Si ratio of 2.0 and an $(\mathrm{Al}: \mathrm{Si})_{\mathrm{i}}$ ratio of $0.07 . \mathrm{b}$ ) DFT calculated ${ }^{29} \mathrm{Si}$ isotropic chemical shifts of the C-A-S-H structural units plotted according to $\mathrm{Q}^{(\mathrm{n})}$ speciation. Reproduced from ref. [28] with permission.

Table 1. DFT calculated mean values of ${ }^{29} \mathrm{Si}$ isotropic chemical shifts and the bond lengths of bridging Si-O. Reproduced from ref. [28], with permission.

\begin{tabular}{|l|l|l|l|}
\hline Species & $\delta_{\text {iso }}\left({ }^{29} \mathbf{S i}\right)(\mathbf{p p m})$ & $\mathbf{d}_{\text {Al-OSi }}(\AA)$ & $\mathbf{d}_{\text {Si-OAl }}(\mathbf{A})$ \\
\hline $\mathbf{Q}^{(2 \mathrm{p}, 1[4] \mathrm{Al})}$ & $-82.5 \pm 1.0$ & $1.77 \pm 0.02$ & $1.65 \pm 0.01$ \\
\hline $\mathbf{Q}^{(2 \mathrm{p}, 1[[] \mathrm{A}])}$ & $-79.1 \pm 2.6$ & $1.87 \pm 0.04$ & $1.63 \pm 0.01$ \\
\hline
\end{tabular}

and $\mathrm{Q}^{(2 \mathrm{p}, 1[4] \mathrm{Al})}$ distributions were $-79.1 \mathrm{ppm}$ and $-82.5 \mathrm{ppm}$, respectively. Therefore, we concluded that the $5 \mathrm{ppm}{ }^{27} \mathrm{Al}$ NMR signal, previously assigned to $\mathrm{TAH}$ in fact arises from bridging ${ }^{[6]}$ Al species in C-A-S-H.

\section{Conclusions}

Combining DNP enhanced solid-state NMR and DFT using the C-S-H brick model, ${ }^{29]}$ we determined with greater detail the atomic-level structure of $\mathrm{C}-\mathrm{A}-\mathrm{S}-\mathrm{H}$ at $\mathrm{Ca}: \mathrm{Si} \geq 1.0 .{ }^{[28]}$

Bridging four-, five-, and six-coordinate aluminates are all present. Our DFT calculations and ${ }^{27} \mathrm{Al}$ NMR strongly supported that the $5 \mathrm{ppm}$ signal that is conventionally assigned to a TAH, belongs to $\left[\mathrm{AlO}_{2}(\mathrm{OH})_{4}\right]^{5-}$ moieties within C-A-S-H. ${ }^{[28]}$

\section{Acknowledgement}

The authors would like to thank the Swiss National Foundation for financing this work grant nos. 153044 and 200020_178860. The authors 
would also want to thank all the co-workers involved in the paper reviewed in this article, A. Kunhi Mohamed, P. Berruyer, B. J. Walder, J. Siramanont, M. Harris, M. Negroni, S. C. Galmarini, S. C. Parker, and K. L. Scrivener

Received: February 5, 2021

[1] Usgs, 'Mineral Commodity Summaries 2019', https://www.usgs.gov/centers/nmic/cement-statistics-and-information (accessed Oct 15, 2019), https://doi.org/10.3133/70202434, 2019.

[2] V. M. Vanderley, B. L. Damineli, M. Quattrone, R. G. Pileggi, Cem. Concr. Res. 2018, 114, 65, https://doi.org/10.1016/j.cemconres.2017.09.013

[3] B. Lothenbach, K. Scrivener, R. D. Hooton, Cem. Concr. Res. 2011, 41, 1244, https://doi.org/10.1016/j.cemconres.2010.12.001

[4] P. J. M. Monteiro, S. A. Miller, A. Horvath, Nat. Mater. 2017, 16, 698 , https://doi.org/10.1038/nmat4930

[5] K. Scrivener, F. Martirena, S. Bishnoi, S. Maity, Cem. Concr. Res. 2018, 114, 49, https://doi.org/10.1016/j.cemconres.2017.08.017

[6] K. L. Scrivener, E. M. Gartner, Cem. Concr. Res. 2018, 114, 2 , https://doi.org/10.1016/j.cemconres.2017.08.017

[7] A. J. Allen, J. J. Thomas, H. M. Jennings, Nat. Mater. 2007, 6, 311, doi:10.1038/nmat 1871

[8] A. Nonat, Cem. Concr. Res. 2004, 34, 1521, https://doi.org/10.1016/j.cemconres.2004.04.035

[9] M. Antoni, J. Rossen, F. Martirena, K. Scrivener, Cem. Concr. Res. 2012, 42, 1579, https://doi.org/10.1016/j.cemconres.2012.09.006

[10] E. Berodier, K. Scrivener, Cem. Concr. Res. 2015, 73, 25, http://dx.doi.org/10.1016/j.cemconres.2015.02.025

[11] A. Schöler, B. Lothenbach, F. Winnefeld, M. B. Haha, M. Zajac, H. M. Ludwig, Cem. Concr. Res. 2017, 93, 71, https://doi.org/10.1016/j.cemconres.2016.11.013

[12] C. Targan, A. Olgun, Y. Erdogan, V. Sevinc, Cem. Concr. Res. 2002, 32, 1551, https://doi.org/10.1016/S0008-8846(02)00831-1

[13] A. C. A. Muller, K. L. Scrivener, A. M. Gajewicz, P. J. McDonald, J. Phys. Chem. C 2013, 117, 403, https://doi.org/10.1021/jp3102964

[14] I. G. Richardson, Cem. Concr. Res. 1999, 29, 1131, https://doi.org/10.1016/S0008-8846(99)00168-4

[15] M. J. Abdolhosseini Qomi, K. J. Krakowiak, M. Bauchy, K. L. Stewart, R. Shahsavari, D. Jagannathan, D. B. Brommer, A. Baronnet, M. J. Buehler, S. Yip, Nat. Commun. 2014, 5, 4960, https://doi.org/10.1038/ncomms5960

[16] A. Kumar, B. J. Walder, A. K. Mohamed, A. Hofstetter, B. Srinivasan, A. J. Rossini, K. Scrivener, L. Emsley, P. Bowen, J. Phys. Chem. C 2017, 121 , 17188, https://doi.org/10.1021/acs.jpcc.7b02439

[17] I. G. Richardson, Cem. Concr. Res. 2004, 34, 1733, https://doi.org/10.1016/j.cemconres.2004.05.034

[18] M. D. Andersen, H. J. Jakobsen, J. Skibsted, Inorg. Chem. 2003, 42, 2280, https://doi.org/10.1021/ic020607b

[19] M. D. Andersen, H. J. Jakobsen, J. Skibsted, Cem. Concr. Res. 2006, 36, 3, https://doi.org/10.1016/j.cemconres.2005.04.010

[20] P. Faucon, A. Delagrave, C. Richet, J. M. Marchand, H. Zanni, J. Phys. Chem. B 1999, 103, 7796, https://doi.org/10.1021/jp990609q

[21] H. Manzano, J. S. Dolado, A. Ayuela, J. Phys. Chem. B 2009, 113, 2832, https://doi.org/10.1021/jp804867u

[22] L. Pegado, C. Labbez, S. V. Churakov, J. Mater. Chem. A 2014, 2, 3477, https://doi.org/10.1039/C3TA14597B

[23] I. G. Richardson, A. R. Brough, R. Brydson, G. W. Groves, C. M. Dobson, J. Am. Ceram. Soc. 1993, 76, 2285, https://doi.org/10.1111/j.1151-2916.1993.tb07765.x

[24] I. G. Richardson, G. W. W. Groves, Cem. Concr. Res. 1993, 23, 131 , https://doi.org/10.1016/0008-8846(93)90143-W
[25] Z. Dai, T. T. Tran, J. Skibsted, J. Am. Ceram. Soc. 2014, 97, 2662, https://doi.org/10.1111/jace.13006

[26] G. K. Sun, J. F. Young, R. J. Kirkpatrick, Cem. Concr. Res. 2006, 36, 18 , https://doi.org/10.1016/j.cemconres.2005.03.002

[27] X. Pardal, F. Brunet, T. Charpentier, I. Pochard, A. Nonat, Inorg. Chem. 2012, 51, 1827, https://doi.org/10.1021/ic202124x

[28] A. Kunhi Mohamed, P. Moutzouri, P. Berruyer, B. J. Walder, J. Siramanont, M. Harris, M. Negroni, S. C. Galmarini, S. C. Parker, K. L. Scrivener, L. Emsley, P. Bowen, J. Am. Chem. Soc. 2020, 142, 11060, https://doi.org/10.1021/jacs.0c02988

[29] A. Kunhi Mohamed, S. C. Parker, P. Bowen, S. Galmarini, Cem. Concr. Res. 2018, 107, 221, https://doi.org/10.1016/j.cemconres.2018.01.007

[30] D. A. Hall, D. C. Maus, G. J. Gerfen, S. J. Inati, L. R. Becerra, F. W. Dahlquist, R. G. Griffin, Science 1997, 276, 930, https://doi.org/10.1126/science.276.5314.930

[31] G. T. Maly, V. S. Debelouchina, K.-N. Bajaj, C.-G. Hu, C.-G. Joo, M. L. Mak-Jurkauskas, J. R. Sirigiri, P. C. A. van der Wel, J. Herzfeld, R. J. Temkin, R. G. Griffin, J. Chem. Phys. 2008, 128, 052211, https://doi.org/10.1063/1.2833582.

[32] Q. Z. Ni, E. Daviso, T. V. Can, E. Markhasin, S. K. Jawla, T. M. Swager, R. J. Temkin, J. Herzfeld, R. G. Griffin, Acc. Chem. Res. 2013, 46, 1933 , https://doi.org/10.1021/ar300348n

[33] A. J. Rossini, A. Zagdoun, M. Lelli, A. Lesage, C. Copret, L. Emsley, Acc. Chem. Res. 2013, 46, 1942, https://doi.org/10.1021/ar300322x

[34] E. L'Hôpital, B. Lothenbach, D. A. Kulik, K. Scrivener, Cem. Concr. Res. 2016, 85,111 , https://doi.org/10.1016/j.cemconres.2016.01.014

[35] R. J. Myers, S. A. Bernal, R. San Nicolas, J. L. Provis, Langmuir 2013, 29 , 5294, https://doi.org/10.1021/la4000473

[36] A. Lesage, M. Lelli, D. Gajan, M. A. Caporini, V. Vitzthum, P. Miville, J. Alauzun, A. Roussey, C. Thieuleux, A. Mehdi, G. Bodenhausen, C. Coperet, L. Emsley, J. Am. Chem. Soc. 2010, 132, 15459, https://doi.org/10.1021/ja104771z

[37] C. Sauve, M. Rosay, G. Casano, F. Aussenac, R. T. Weber, O. Ouari, P. Tordo, Angew. Chem. Int. Ed. 2013, 52, 10858, https://doi.org/10.1002/anie.201304657

[38] A. Pines, M. G. Gibby, J. S. Waugh, J. Chem. Phys. 1973, 59, 569 , https://doi.org/10.1063/1.1680061

[39] J. Skibsted, E. Henderson, H. J. Jakobsen, Inorg. Chem. 1993, 32, 1013 , https://doi.org/10.1021/ic00058a043

[40] J. Trebosc, B. Hu, J. P. Amoureux, Z. Gan, J. Magn. Reson. 2007, 186, 220 , https://doi.org/10.1016/j.jmr.2007.02.015

[41] S. Komarneni, R. Roy, D. M. Roy, C. A. Fyfe, G. J. Kennedy, A. A Bothner-By, J. Dadok, A. S. Chesnick, J. Mater. Chem. A 1985, 20, 4209, https://doi.org/10.1007/BF00552416

[42] E. Lippmaa, M. Maegi, A. Samoson, M. Tarmak, G. Engelhardt, J. Am. Chem. Soc. 1981, 103, 4992, https://doi.org/10.1021/ja00407a002

[43] J. H. Baltisberger, P. Florian, E. G. Keeler, P. A. Phyo, K. J. Sanders, P. J. Grandinetti, J. Magn. Reson. 2016, 268, 95, http://dx.doi.org/10.1016/j.jmr.2016.05.003

[44] H. Lechert, Ber. Bunsengesell. für Phys. Chemie 1988, 92, 1059 , https://doi.org/10.1002/bbpc.198800267.

\section{License and Terms}

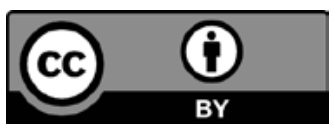

This is an Open Access article under the terms of the Creative Commons Attribution License CC BY 4.0. The material may not be used for commercial purposes.

The license is subject to the CHIMIA terms and conditions: (http:// chimia.ch/component/sppagebuilder/?view=page $\& i d=12$ ).

The definitive version of this article is the electronic one that can be found at https://doi.org/10.2533/chimia.2021.272 